\title{
Effect of stand density on longitudinal variation of wood and bark growth in fast-growing Eucalyptus plantations
}

\author{
Fernanda M Guedes Ramalho ${ }^{(1)}$, \\ Emanuella Mesquita Pimenta ${ }^{(1)}$, \\ Caio Palmeira Goulart ${ }^{(1)}$, \\ Maria N Félix De Almeida ${ }^{(2)}$, \\ Graziela Baptista Vidaurre ${ }^{(2)}$, \\ Paulo Ricardo Gherardi Hein ${ }^{(1)}$
}

The influence of tree spacing on the wood/bark ratio is unknown in young fastgrowing Eucalyptus trees. The objective of this study was to evaluate the effect of plant spacing on the wood and bark production along the Eucalyptus stem. Four genetic materials were planted in four spacings: $3 \times 1 \mathrm{~m}, 3 \times 2 \mathrm{~m}$, $3 \times 3 \mathrm{~m}$ and $3 \times 4 \mathrm{~m}$. Three 5-year-old trees from each clone and in each plant spacing were harvested. Cross-sectional discs (thickness: $30 \mathrm{~mm}$ ) were cut from each tree along the stem $(0 \%, 25 \%, 50 \%, 75 \%$ and $100 \%$ of the total tree height) and at $1.3 \mathrm{~m}$ above ground, totaling 288 disks (4 spacings $\times 4$ clones $\times$ 3 replicates $\times 6$ axial positions). The wood thickness was measured at six random and equidistant points around the perimeter using a gauge and means were calculated from each disc. Six cross diameters were measured for each debarked disc. After obtaining the averaged bark thickness and wood diameter, the bark content was calculated as the ratio between the surface area occupied by the bark and the total area of the stem in each level. In the narrowed plant spacing $(3 \times 1)$, the trees had a mean diameter of $7.4 \mathrm{~cm}$, while at the spacing $3 \times 4$ the diameter of the trees was $91 \%$ higher $(14.11 \mathrm{~cm})$ at breast height. The increase in plant spacing from 3 to $12 \mathrm{~m}^{2}$ per tree resulted in an increase in bark thickness (56.7\%) from $1.94 \mathrm{~mm}$ to $3.04 \mathrm{~mm}$, but caused a reduction of bark content $(16 \%)$ from $9.66 \%$ to $8.11 \%$. Our findings show that trees grown under wider spacing tend to produce thicker bark. The bark thickness and the effect of plant spacing on the bark thickness decreased in the base-top direction. The correlation between bark thickness and wood diameter increases from 0.682 to 0.825 with the increase of spacing between trees. In contrast, the bark thickness to bark content correlation decrease from 0.735 to 0.15 with increased plant spacing. The stand density significantly af fected the variation of the stem diameter, bark thickness and bark content of Eucalyptus plantations.

Keywords: Stand Density, Timber, Bark, Silvicultural Treatment, Forest Productivity

tion surface reached 7.84 million hectares, with $72.3 \%$ being Eucalyptus and $20.15 \%$ Pinus in 2016 (IBA 2017). The timber produced in Brazil is industrially used as raw material for pulp and paper, charcoal, solid products and engineered products. The industrial use of wood requires harvesting, handling and debarking processes resulting in huge amount of bark. According to Sette et al. (2018) the quantity of wood residues generated by forest-based industries in Brazil was estimated at approximately 13.8 million tons in 2016.

Tree barks are complex biomass components with a large structural and chemical diversity among species (Miranda et al. 2016). It is made of lignocellulosic material with different functions in trees, including transport and storage of nutrients, and protection against environmental hazards (Reina et al. 2016). According to Neiva et al. (2018) the tree bark should be valued for two reasons: (i) large availability as byproducts or residues in wood-based industries; and (ii) intrinsic characteristics that include a large structural diversity and chemical richness, allowing multiple product target- ing and high potential value for biorefineries.

Miranda et al. (2016) reported that bark has been used traditionally, e.g., as a source of drugs, materials and energy, and is today viewed as a potential resource for biorefineries. Most Brazilian pulp and paper industries use bark as an energy source due to its abundance and operational ease. However, alternative uses for the massive amount of inexpensive biomass waste have been proposed, e.g., as natural antioxidants (Vázquez et al. 2008) and antimicrobial agents (Weerakkody et al. 2011, Parreira et al. 2017). Several studies have demonstrated the potential use of bark as biosorbent for wastewater (Sarin \& Pant 2006) and textile effluents (Morais et al. 1999), including adsorbents in the form of activated carbon powder (Patnukao \& Pavasant 2008) and hydrochar (Gao et al. 2016). In short, the bark of trees can be used as low-cost adsorbents for the removal of heavy metals, organics, phosphate and pathogens. Regarding the alternative energy applications, several studies have evaluated the use of bark for biofue 
feedstock production (Lima et al. 2013, Romaní et al. 2018) and briquettes (Sette et al. 2018). Neiva et al. (2018) assessed the potential of Eucalyptus bark as a biorefinery feedstock and suggested applying it in the food and pharmaceutical industries as well as for polysaccharides valorization.

Bark is important for the survival of the tree. According to Burger \& Richter (1991) the bark has the function of protecting the plant against dryness, fungal attacks, mechanical injuries and climatic variations, in addition to the storage and conduction of nutrients provided by the phloem. Moreover, numerous medicines and important technological products have been obtained from the bark of forest trees and shrubs (Gottesfeld 1992). Despite being physiologically important, the presence of bark is currently undesirable for most industrial applications. Trees produce large amounts of bark during their growth; in Eucalyptus globulus, the bark content varies from $15.2 \%$ for trees with 7 to 11 years of age (Ramírez et al. 2009, Miranda et al. 2016) to $17.4 \%$ for 18 -year-old trees (Miranda \& Pereira 2015).

It is well known that variations in silvicultural treatments and forest management strategies cause changes in tree growth and wood properties (Zobel \& Jett 1995). The effect of the plantation spacing on wood density has been widely investigated and many studies reported variable trends in Eucalyptus, as pointed out by Resquin et al. (2019). However, the influence of plant spacing on bark production is not well established. According to Quilho \& Pereira (2001), the bark content is a relevant production parameter that accounts for an important percentage of the merchantable bole dry weight.

Quilho \& Pereira (2001) have evaluated within and between-tree variation of bark content in Eucalyptus globulus in Portugal and stated that bark thickness was higher in the site with better growth and always decreased from the tree base to the top. Miranda \& Pereira (2015) have investigated variation in wood and bark characteristics in Eucalyptus globulus trees grown with different planting densities in Portugal and reported that bark content varied from 13.4 to $14.4 \%$ of the stem volume. In Brazil, Rocha et al. (2016) assessed the influence of plant spacing on wood and bark density in 7-year-old Eucalyptus hybrids grown in northern Minas Gerais, Brazil and concluded that trees at wider spacings $\left(9 \mathrm{~m}^{2}\right)$ produce bark with greater density than at narrowed spacings $\left(1.5 \mathrm{~m}^{2}\right)$. Rocha et al. (2018) evaluated the effect of different plant spacings on bark thickness and properties in Eucalyptus grandis $\times$ E. camaldulensis and reported that plant spacing positively affects bark properties. Martins et al. (2019) have quantified the macronutrients of 12-year-old Eucalyptus bark planted at three planting densities, concluding that higher plant density contributed to higher bark production and greater nutrient accumulation per area.

Overall, the aforementioned studies proved that growth conditions and tree physiology do influence wood and bark production and properties. However, further investigations are needed to fully understand the effect of plant spacing on wood and bark production in Eucalyptus clones. For example, it is necessary to throw light on how the bark thickness varies along the stem, from the base to the treetop, to adapt the forest management towards the optimum production of raw material. In this study, our starting hypothesis is that stand density greatly affects the

Tab. 1 - Descriptive statistics of bark thickness, bark content and stem (wood) diameter at $1.3 \mathrm{~m}$ above ground of Eucalyptus planted at different spacings. Different letters indicate significant difference $(p<0.05)$ between means after Tukey test.

\begin{tabular}{|c|c|c|c|c|c|c|c|}
\hline Property & $\begin{array}{l}\text { Plant } \\
\text { spacing } \\
(m \times m)\end{array}$ & $\begin{array}{c}\text { Stand } \\
\text { density } \\
\left(\text { trees ha }^{-1}\right)\end{array}$ & $\mathbf{N}$ & Mean & Min & Max & $\begin{array}{l}\text { CV } \\
\text { (\%) }\end{array}$ \\
\hline \multirow{5}{*}{$\begin{array}{l}\text { Bark } \\
\text { thickness } \\
(\mathrm{mm})\end{array}$} & $3 \times 1$ & 3333 & 16 & $1.94^{\mathrm{b}}$ & 1.00 & 2.67 & 25.30 \\
\hline & $3 \times 2$ & 1667 & 16 & $2.60^{\mathrm{a}}$ & 2.00 & 3.67 & 20.10 \\
\hline & $3 \times 3$ & 1111 & 16 & $2.72^{\mathrm{a}}$ & 2.00 & 4.00 & 25.30 \\
\hline & $3 \times 4$ & 833 & 16 & $3.04^{\mathrm{a}}$ & 2.67 & 3.67 & 10.49 \\
\hline & Total & - & 64 & 2.57 & 1.00 & 4.00 & 25.34 \\
\hline \multirow{5}{*}{$\begin{array}{l}\text { Bark } \\
\text { content } \\
(\%)\end{array}$} & $3 \times 1$ & 3333 & 16 & $9.66^{a}$ & 5.69 & 13.87 & 24.36 \\
\hline & $3 \times 2$ & 1667 & 16 & $9.22^{\mathrm{ab}}$ & 7.53 & 12.11 & 14.55 \\
\hline & $3 \times 3$ & 1111 & 16 & $7.85^{b}$ & 5.43 & 11.62 & 23.98 \\
\hline & $3 \times 4$ & 833 & 16 & $8.11^{\mathrm{ab}}$ & 6.32 & 9.77 & 13.18 \\
\hline & Total & - & 64 & 8.70 & 5.43 & 13.87 & 21.38 \\
\hline \multirow{5}{*}{$\begin{array}{l}\text { Wood } \\
\text { diameter } \\
(\mathrm{cm})\end{array}$} & $3 \times 1$ & 3333 & 16 & $7.40^{d}$ & 6.53 & 8.27 & 7.33 \\
\hline & $3 \times 2$ & 1667 & 16 & $10.44^{c}$ & 9.27 & 11.53 & 6.38 \\
\hline & $3 \times 3$ & 1111 & 16 & $12.98^{b}$ & 11.80 & 14.13 & 5.08 \\
\hline & $3 \times 4$ & 833 & 16 & $14.11^{a}$ & 12.93 & 16.07 & 6.46 \\
\hline & Total & - & 64 & 11.23 & 6.53 & 16.07 & 23.98 \\
\hline
\end{tabular}

variation of the tree diameter along stem, whereas the bark thickness remains uniform independent of the tree spacing. However, the combination of these two variables result in bark content variation in Eucalyptus plantations.

The objective of the present study was to evaluate the interaction between genetic material and plant spacing in the production of wood and bark and to evaluate the effect of plant spacing on the longitudinal variation of wood and bark production in Eucalyptus clones.

\section{Material and methods}

Plant material, planting density and disc sampling

We used commercial planted clones of Eucalyptus urophylla x E. grandis hybrids from a clonal test established by Suzano Papel e Celulose S.A. in the municipality of Itamarandiba, MG, Brazil ( $17^{\circ} 51^{\prime} \mathrm{S}, 42^{\circ} 51^{\prime}$ W; elevation: $910 \mathrm{~m}$ a.s.l.). The average annual rainfall of the region is $1000 \mathrm{~mm}$, with soil classified as Yellow Latosol. The material used in the study was managed for cellulose production.

Four different clones were planted in four plant spacings: $3 \times 1 \mathrm{~m}, 3 \times 2 \mathrm{~m}, 3 \times 3 \mathrm{~m}$ and $3 \times 4 \mathrm{~m}$, resulting in stand densities of 3333 , 1667,1111 and 833 trees ha ${ }^{-1}$, respectively. Three trees from each clone in each spacing were harvested at 5 years of age (totaling 48 trees).

Cross-sectional discs (thickness: $30 \mathrm{~mm}$ ) were cut from each tree along the stem at different heights (0\%, 25\%, 50\%, 75\% and $100 \%$ of the total tree height) and at breast height $(1.3 \mathrm{~m}$ ), totaling 288 discs (4 spacings $\times 4$ clones $\times 3$ replicates $\times 6$ longitudinal positions).

\section{Determination of wood and bark production}

Wood production was analyzed based on the debarked wood discs. The term "wood diameter" used hereafter refers to the diameter of the wooden disc, disregarding the bark. The wood discs were dried and sanded before analysis. The wood thickness was measured at 6 random and equidistant points around the perimeter using a gauge and means were calculated for each disc. Six cross diameters were measured for each debarked disc. After obtaining the averaged bark thickness and wood diameter, the bark content was calculated as the ratio between the area occupied by the bark and the total area determined as a function of bark thickness and wood diameter, as described in Silva et al. (2018).

\section{Statistical analysis}

The software SPSS Statistics ${ }^{\circledR}$ v.19 (IBM, Armonk, NY, USA) was used for descriptive statistics, analysis of variance and multiple comparison of means (Tukey test, $a=$ $0.05)$. For the analysis of variance, the fourlevel spacing was considered as the source 
of variation. The analyses were done separately for each height. Pearson's correlation coefficients were calculated between bark and growth characteristics of Eucalyptus clones at different planting densities.

\section{Results and discussion}

Effect of plant spacing on wood and bark growth in Eucalyptus plantations

Tab. 1 shows that the plant spacing significantly affected the variation of wood diameter, bark thickness and bark content at breast height $(1.3 \mathrm{~m})$ in Eucalyptus clones. In the narrowest plant spacing $(3 \times 1 \mathrm{~m})$, the trees had a mean diameter of $7.4 \mathrm{~cm}$, while at the widest plant spacing $(3 \times 4 \mathrm{~m})$, the diameter of the trees was $91 \%$ higher (14.11 $\mathrm{cm}$ ) at breast height. The increase in plant spacing from 3 to $12 \mathrm{~m}^{2}$ per tree resulted in an increase in bark thickness from $1.94 \mathrm{~mm}$ to $3.04 \mathrm{~mm}$ (increase of $56.7 \%$ ), but caused a reduction of bark content from $9.66 \%$ to $8.11 \%$ (reduction of $16 \%$ ) in the trees of the plantations. These findings show that the tree stem diameter and bark thickness increase proportionally as the plant spacing increase, but the bark content of the trees decreases.

The bark content of 5-year-old Eucalyptus observed in this study is lower than that reported for older trees. For example, Ramírez et al. (2009) investigated fourteen 7year-old $E$. globulus clones grown in Chile, reporting an average bark content of $15.2 \%$ (range: 9.6 to 20.8\%). Miranda et al. (2016) studied 11-year-old E. globulus trees grown in Portugal with an average bark content of $15.2 \%$, varying from 9.6 to $23 \%$. Miranda \& Pereira (2015) have investigated E. globulus trees at 18 years of age and found a mean bark content of $17.4 \%$ of the total stem volume for second rotation trees and $13.8 \%$ for first rotation trees at the same age. Silva et al. (2018) assessed the variation in bark content and thickness of 4.5 year-old Eucalyptus and Acacia planted in pure and mixed stands. The bark content and bark thickness of Acacia trees in monoculture $(47.5 \%$ and $1.32 \mathrm{~cm}$ ) were approximately three times higher than those from mixed stand $(15.2 \%$ and $0.51 \mathrm{~cm})$. However, no effect was reported for Eucalyptus plantations.

Tab. 1 shows that the stand density simultaneously affects the stem diameter and bark thickness of Eucalyptus trees. However, the variation in stem diameter was influenced by stand density more than bark thickness. As these two variables are correlated, the bark content of trees can be controlled by the plant spacing in Eucalyptus plantations.

Plant spacing affects wood longitudinal variation and bark growth

Plant spacing significantly influenced the longitudinal variation of the wood diameter of Eucalyptus clones (Fig. 1). Our findings show that the longitudinal variation of bark thickness is larger in the trees planted

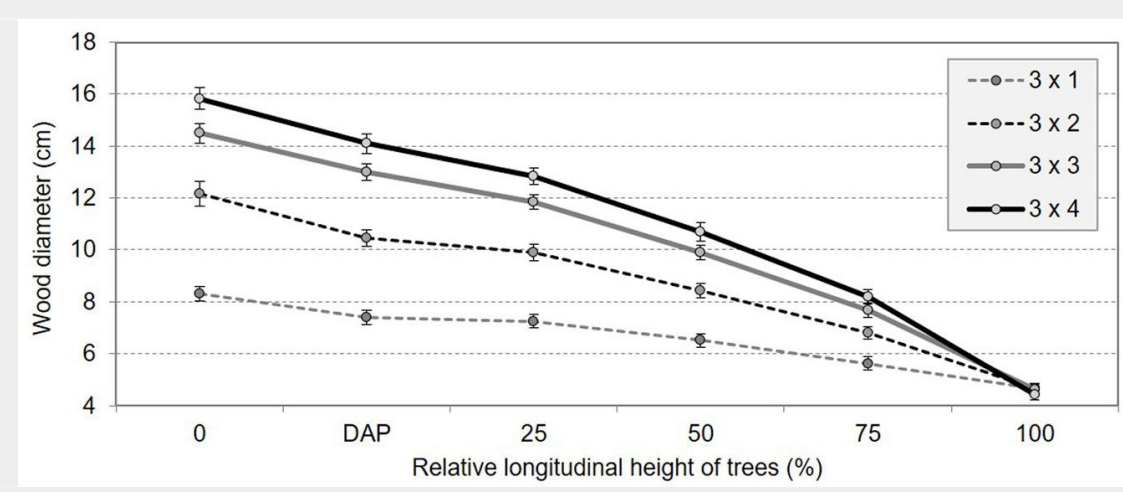

Fig. 1 - Effect of plant spacing on the longitudinal variation of wood diameter in Eucalyptus plantations. Error bars represent the standard error. at wider spacings. In the most widely spaced plantation ( 833 trees ha ${ }^{-1}$ ), the mean diameter at the tree base was 15.83 $\mathrm{cm}$, while in the most densely planted trees (3333 trees ha $\left.{ }^{-1}\right)$ it was lower by $47 \%$ (8.32 $\mathrm{cm})$. The effect of spacing on stem diameter of trees decreased with height.

Variations in stand densities are known to influence the tree growth in various species. For instance, Niemistö (1995) has investigated the taper variation in trees of Silver Birch (Betula pendula) as a function of density in stands varying from 400 to 5000 trees, showing that stem taper (expressed as the difference in diameter between breast height and the height of 6.om) decreases as stand density increases. Will et al. (2005) have studied intensively managed, 4-year-old loblolly pine (Pinus taeda L.) stands planted at different densities and reported that DBH declined from 9.1 to $6.3 \mathrm{~cm}$ as planting density in- creased from 740 to 4440 trees ha ${ }^{-1}$. Gomat et al. (2011) studied the factors affecting stem taper variation in Eucalyptus grown in the Republic of Congo. According to their results, tree shape markedly changes between 1 and 2 years of age and from 3 years onwards, and the buttresses increase with stand age. However, planting density in the latter study $(500,700,800,1100$ and 1300 trees ha ${ }^{-1}$ ) had no significant influence on the stem profile. In this study, the stand density was higher, ranging from 833 to 3333 trees ha $\mathrm{h}^{-1}$, and the difference in growth between clones was remarkable (Fig. 1).

Fig. 2 shows the effect of plant spacing on the longitudinal variation of bark thickness and bark content in Eucalyptus clones. We found that trees grown at wider spacing tend to produce a thicker bark along the stem. The bark thickness and the effect of plant spacing on the bark thickness de-
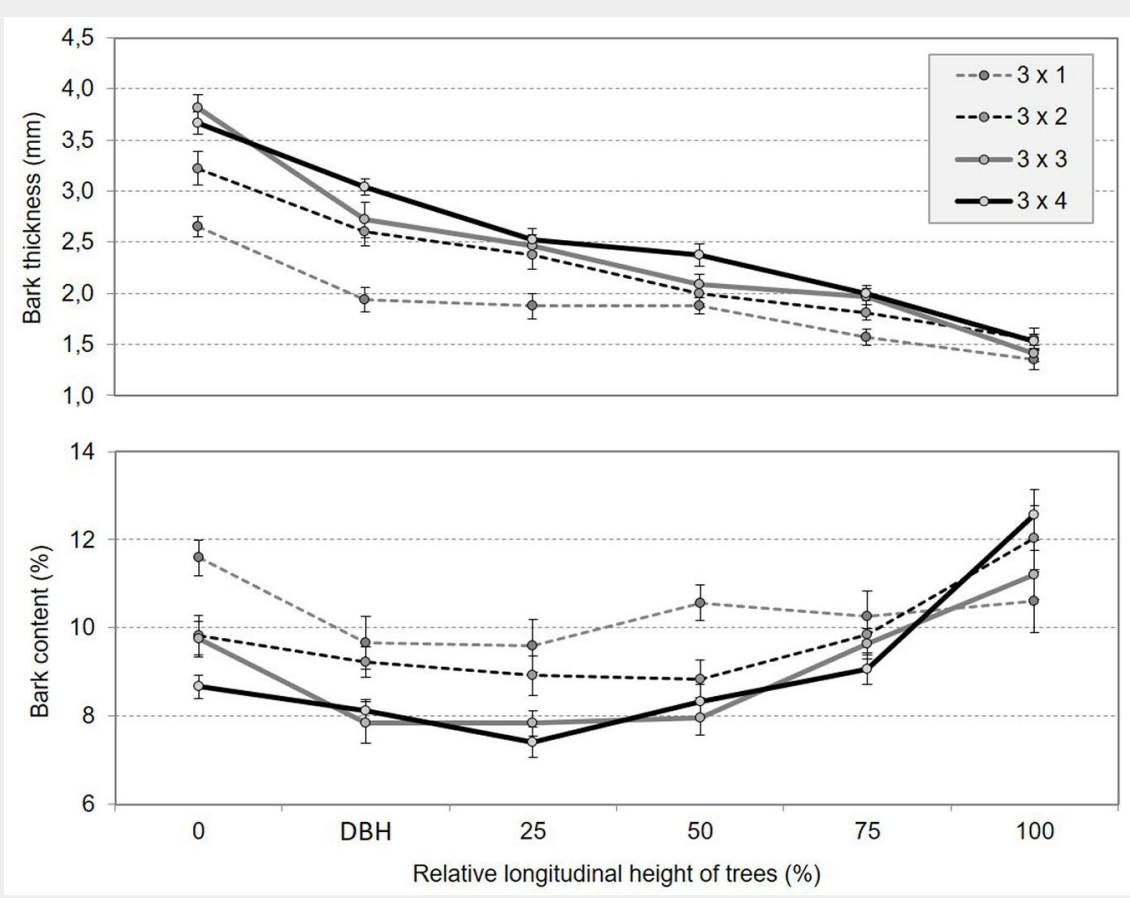

Fig. 2 - Effect of spacing on the longitudinal variation of bark thickness and bark content in Eucalyptus plantations. 
Tab. 2 - Pearson's correlation coefficients between bark and growth characteristics of Eucalyptus clones at different planting densities. Correlation values above the diagonal refers to wood diameter with bark, while correlation values below diagonal refers to wood diameter without bark. $\left({ }^{* *}\right)$ : $p<0.01 ;\left(^{* *}\right)$ : $p<0.01 ;(*): p<0.05 ;(n s)$ : non significant.

\begin{tabular}{|c|c|c|c|c|}
\hline $\begin{array}{c}\text { Plant } \\
\text { spacing }\end{array}$ & Characteristic & $\begin{array}{c}\text { Bark } \\
\text { thickness }\end{array}$ & $\begin{array}{c}\text { Bark } \\
\text { content }\end{array}$ & $\begin{array}{c}\text { Wood } \\
\text { diameter }\end{array}$ \\
\hline \multirow[t]{3}{*}{$3 \times 1$} & Bark thickness & - & $0.735^{* * *}$ & $0.678^{* * *}$ \\
\hline & Bark content & $0.735^{* * *}$ & - & $0.023^{\text {ns }}$ \\
\hline & Wood diameter & $0.628^{* * *}$ & $0.041^{\mathrm{ns}}$ & $0.998^{* * *}$ \\
\hline \multirow[t]{3}{*}{$3 \times 2$} & Bark thickness & - & $0.321^{* *}$ & $0.667^{* * *}$ \\
\hline & Bark content & $0.321^{* *}$ & - & $-0.311^{* *}$ \\
\hline & Wood diameter & $0.615^{* * *}$ & $-0.343^{* * *}$ & $0.998^{* * *}$ \\
\hline \multirow[t]{3}{*}{$3 \times 3$} & Bark thickness & - & $0.289^{* *}$ & $0.781^{* * *}$ \\
\hline & Bark content & $0.289^{* *}$ & - & $-0.339^{* * *}$ \\
\hline & Wood diameter & $0.760^{* * *}$ & $-0.368^{* * *}$ & $0.999^{* * *}$ \\
\hline \multirow[t]{3}{*}{$3 \times 4$} & Bark thickness & - & $0.148^{\mathrm{ns}}$ & $0.837^{* * *}$ \\
\hline & Bark content & $0.148^{\mathrm{ns}}$ & - & $-0.625^{* * *}$ \\
\hline & Wood diameter & $0.825^{* * *}$ & $-0.640^{* * *}$ & $1.000^{* * *}$ \\
\hline \multirow{3}{*}{$\begin{array}{c}\text { All } \\
\text { together }\end{array}$} & Bark thickness & - & $0.161^{*}$ & $0.729^{* * *}$ \\
\hline & Bark content & $0.161^{*}$ & - & $-0.435^{* * *}$ \\
\hline & Wood diameter & $0.704^{* * *}$ & $-0.458^{* * *}$ & - \\
\hline
\end{tabular}

creased in the base-top direction (Tab. 1).

Most studies that investigated the bark content of trees were based on the total bark content expressed as percentage of the total stem (Ramírez et al. 2009, Miranda \& Pereira 2015, Miranda et al. 2016). Quilho \& Pereira (2001) in 15-year-old Eucalyptus globulus trees reported a mean bark content of $11 \%$ of stem dry weight, with higher values in the lower part of the stem ( $14 \%$ at $5 \%$ height level), decreasing to the $35 \%$ of height level ( $9 \%$ ) and increasing again (but less) towards the top (12\% at $75 \%$ height level). Quilho \& Pereira (2001) reported a high bark thickness (6.5 to 9.8 $\mathrm{mm})$ at the stem base which decreased towards the treetop (1.9 to $3.7 \mathrm{~mm}$ ).

We found no evidence in the literature on the longitudinal variation of bark thickness and bark content of Eucalyptus trees planted at different stand densities. Regarding the variation in bark characteristics with stand density, the longitudinal variation in bark density in trees at five different spacing was investigated by Miranda \& Pereira (2015). They reported that bark density was highest at the stump level $(488 \mathrm{~kg}$ $\left.\mathrm{m}^{-3}\right)$, decreased along the stem up to $3.3 \mathrm{~m}$ $\left(462 \mathrm{~kg} \mathrm{~m}^{-3}\right)$ and then remained rather constant at an average of $465 \mathrm{~kg} \mathrm{~m}^{-3}$. However,

Tab. 3 - Effect of stand density on wood and bark productivity per tree and hectare.

\begin{tabular}{cccccc}
\hline $\begin{array}{c}\text { Plant } \\
\text { spacing } \\
(\mathbf{m} \times \mathbf{m})\end{array}$ & $\begin{array}{c}\text { Stand density } \\
\left(\text { trees ha } \mathbf{~}^{-1}\right)\end{array}$ & \multicolumn{2}{c}{$\begin{array}{c}\text { Basal transverse area } \\
\left(\mathrm{cm}^{2} \text { tree }\right.\end{array}$} & \multicolumn{2}{c}{$\begin{array}{c}\text { Basal transverse area } \\
\left(\mathbf{m}^{2} \mathbf{h a}^{-1}\right)\end{array}$} \\
\hline $1 \times 3$ & 3333 & Bark & Wood & Bark & Wood \\
\hline $2 \times 3$ & 1667 & 11.24 & 114.36 & 1.87 & 19.06 \\
\hline $3 \times 3$ & 1111 & 16.07 & 164.85 & 1.79 & 18.31 \\
\hline $4 \times 3$ & 833 & 17.06 & 196.89 & 1.42 & 16.40 \\
\hline
\end{tabular}

the authors did not report significant differences in bark density among trees within each stand density.

The variation in bark thickness along the stem depicted in Fig. 2 shows a pattern similar to those reported in earlier studies on Eucalyptus bark, even in older trees. For instance, Quilho \& Pereira (2001) in 15-yearold E. globulus trees grown in Portugal reported a decrease in the average bark thickness from $9.8 \mathrm{~mm}$ at the base $(5 \%$ of total tree height) to $3.7 \mathrm{~mm}$ at the top (75\% of total tree height) under better growth conditions, and from $6.5 \mathrm{~mm}$ to $1.9 \mathrm{~mm}$ under worse conditions. In short, bark thickness was higher in the sites with better growth conditions and always decreased from the tree base to the top.

\section{Correlations between wood and bark growth}

Tab. 2 summarizes the correlation among wood diameter, bark thickness and bark content in Eucalyptus clones grown under different planting densities. The correlation between bark thickness and wood diameter increased from 0.682 to 0.825 as plant spacing increased from $3 \times 1 \mathrm{~m}$ (3333 trees $\left.\mathrm{ha}^{-1}\right)$ to $3 \times 4 \mathrm{~m}\left(833\right.$ trees ha $\left.{ }^{-1}\right)$. In contrast, the bark thickness to bark content correla- tion decrease from 0.735 to 0.15 as plant spacing increased (Tab. 2).

The variation in correlation between tree growth and proportion of bark is due to the combination of different axial variation rates of bark thickness and stem diameter. As stated by Quilho \& Pereira (2001), the bark thickness at the stem base is higher, thus its increase mostly determines the whole-tree bark content, while towards the treetop the wood diameter decreases more dramatically than bark thickness, thereby increasing the proportion of bark.

The correlation between bark and tree growth characteristics has been previously neglected in similar studies and the trend along the stem of the bark-growth relationship are unknown. However, Eucalyptus bark has been recently claimed as a novel source of biomass for sustainable production of biofuels (Romaní et al. 2018) and the use of bark from the pulp industry for energy production will be reduced over time. According to Neiva et al. (2018) the industrial bark accumulated at mill yards from the harvesting, handling and debarking processes and these residues can be directed to other uses, if proved to be more profitable.

\section{Effect of stand density on wood and bark productivity}

Tab. 1 shows that plant spacing affects the wood and bark growth of forest plantations, especially in the lower part of the stem. However, it is important to note that the widely spaced plantations had more biomass per tree, though the overall production per hectare is lower as pointed out by Miranda \& Pereira (2015). The effect of stand density on wood and bark productivity per tree and hectare is presented in Tab. 3. Wood and bark productivity per individual tree and per hectare were calculated based on the cross-section area at the base of the stem (Tab. 3).

As for the productivity per tree, wider plant spacing tends to yield larger trees with more bark. Tab. 2 shows that at $4 \times 3 \mathrm{~m}$ spacing the production of wood $\left(\sim 197 \mathrm{~cm}^{2}\right)$ and bark $\left(\sim 17 \mathrm{~cm}^{2}\right)$ per tree is $2.6 \mathrm{x}$ and $1.7 \mathrm{x}$ higher, respectively, than for the same clones planted at $1 \times 3 \mathrm{~m}$ spacing. On the other hand, considering the productivity per hectare, trees growing at higher density produce $10.4 \%$ more wood $\left(16.4 \mathrm{~m}^{2} \mathrm{ha}^{-1}\right.$ at $4 \times 3 \mathrm{~m}$ and $18.1 \mathrm{~m}^{2} \mathrm{ha}^{-1}$ at $\left.1 \times 3 \mathrm{~m}\right)$ and $47.7 \%$ more bark $\left(1.42 \mathrm{~m}^{2}\right.$ ha $\mathrm{at}^{-1}$ at $4 \times 3 \mathrm{~m}$ and $2.10 \mathrm{~m}^{2}$ ha ${ }^{-1}$ at $1 \times 3 \mathrm{~m}$ spacing).

The above analysis has considered only the area occupied by wood and bark at the stem base and disregards the fact that tree height is different among the different planting density, which will influence the productivity of wood and bark per tree and per hectare. This analysis allows us to reflect on how the spacing affects the production of wood and bark in the lower part of the stem aiming, for example, at the multiple use biomass as wood for saw mills or lamination. 
In addition to wood and bark yield per tree and per hectare, other factors should be taken into account to establish the optimal spacing for production plantations. For example, the cost of planting, maintainance and harvesting varies according to stand density. According to Niemistö (1995) there is no advantage in exceeding the initial density of 2500 trees per ha in Silver birch (Betula pendula) plantations. In this study, the most adequate density in terms of wood and bark production is still the traditional density of 1100 to 1700 trees per hectare established for most of the forest plantations of pulp and paper companies.

\section{Conclusions}

Our results confirm that stand density simultaneously affects tree stem diameter and bark thickness in Eucalyptus plantations; conversely, the bark content of trees can be controlled by choosing an appropriate plant spacing. At broader plant spacing, the mean diameter at breast height was $91 \%$ higher than that observed at narrower plant spacing. Trees grown in broader plantations tend to produce a thicker bark. Increasing the stand density led to a $56.7 \%$ increase in bark thickness, but caused a reduction of bark content of $16 \%$ at the breast height. The bark thickness and the effect of plant spacing on bark thickness decreased in the base-top direction. The correlation between bark thickness and wood diameter increases with increased plant spacing. Considering the productivity per single tree, wider spacing tends to produce larger trees with more bark.

\section{Acknowledgements}

The authors express special thanks to the Wood Science and Technology Laboratory of the Federal University of Lavras (UFLA, Brazil) for supporting the experimental work and to the Federal University of Espirito Santo (UFES, Brazil) for providing vegetal material. This study was funded by the National Council for Scientific and Technological Development (CNPq Brazil, grant no. 405085/2016-8), Higher Education Personnel Improvement Coordination (CAPES, Brazil) and Foundation for Research Support of the State of Minas Gerais (FAPEMIG Brazil). PRG Hein was supported by CNPq grant no. 303675/2017-9.

\section{References}

Burger LM, Richter HG (1991). Anatomia da madeira [Wood anatomy]. Nobel, São Paulo, Brazil, pp. 154. [in Portuguese]

Gao P, Zhou Y, Meng F, Zhang Y, Liu Z, Zhang W, Xue $G$ (2016). Preparation and characterization of hydrochar from waste eucalyptus bark by hydrothermal carbonization. Energy 97: 238245. - doi: 10.1016/j.energy.2015.12.123

Gomat HY, Deleporte P, Moukini R, Mialounguila G, Ognouabi N, Saya AR, Vigneron P, Saint-Andre $L$ (2011). What factors influence the stem taper of Eucalyptus: growth, environmental conditions, or genetics? Annals of Forest Science 68: 109. - doi: 10.1007/s13595-011-0012-3

Gottesfeld LMJ (1992). The importance of bark products in the aboriginal economies of Northwestern British Columbia, Canada. Economic Botany 46:148. - doi: 10.1007/BF02930629

IBA (2017). Anuário estatístico da Indústria Brasileira de Arvores: ano base 2016 [Statistical yearbook of the Brazilian tree industry: base year 2016]. IBA - Indústria Brasileira de Árvores, Brasília, Brazil, pp. 77. [in Portuguese]

Lima MA, Lavorente GB, Silva HKP, Bragatto J, Rezende CA, Bernardinelli OD, Azevedo ER, Gomez LD, McQueen-Mason SJ, Labate CA, Polikarpov I (2013). Effects of pretreatment on morphology, chemical composition and enzymatic digestibility of Eucalyptus bark: a potentially valuable source of fermentable sugars for biofuel production - part 1. Biotechnology for Biofuels 6: 75. - doi: 10.1186/1754-6834-6-75

Martins TGV, Rocha MFV, Nieri EM, Melo LA, Silva MLS, Silva DSN (2019). Nutrient accumulation in Eucalyptus bark at different population densities. Revista Brasileira de Engenharia Agrícola e Ambiental 23 (1): 40-46. - doi: 10.1590/ 1807-1929/agriambi.v23n1p40-46

Miranda I, Lima L, Quilhó T, Knapic S, Pereira H (2016). The bark of Eucalyptus sideroxylon as a source of phenolic extracts with anti-oxidant properties. Industrial Crops and Products 82: 81-87. - doi: 10.1016/j.indcrop.2015.12.003

Miranda I, Pereira H (2015). Variation of wood and bark density and production in coppiced Eucalyptus globulus trees in a second rotation. iForest - Biogeosciences and Forestry 9: 270275. - doi: 10.3832/ifor1442-008

Morais LC, Freitas OM, Gonçalves EP, Vasconcelos LT, González Beça CG (1999). Reactive dyes removal from wastewaters by adsorption on Eucalyptus bark: variables that define the process. Water Research 33 (4): 979-988. - doi: 10.1016/S0043-1354(98)00294-2

Neiva DM, Araújo S, Gominho J, Carneiro AC, Pereira H (2018). Potential of Eucalyptus globulus industrial bark as a biorefinery feedstock: Chemical and fuel characterization. Industrial Crops and Products 123: 262-270. - doi: 10.1016/j. indcrop.2018.06.070

Parreira P, Soares BIG, Freire CSR, Silvestre AJD, Reis CA, Martins MCL, Duarte MF (2017). Eucalyptus spp. outer bark extracts inhibit Helicobacter pylori growth: in vitro studies. Industrial Crops and Products 105: 207-214. - doi: 10.1016/j.indcrop.2017.05.012

Patnukao P, Pavasant P (2008). Activated carbon from Eucalyptus camaldulensis Dehn bark using phosphoric acid activation. Bioresource Technology 99 (17): 8540-8543. - doi: 10.1016/j.biortech.2006.10.049

Niemistö P (1995). Influence of initial spacing and row-to-row distance on the crown and branch properties and taper of silver birch (Betula pendula). Scandinavian Journal of Forest Research 10 (1-4): 235-244. - doi: 10.1080/02827 589509382889

Quilho T, Pereira H (2001). Within and betweentree variation of bark content and wood density of Eucalyptus globulus in commercial plantations. lawa Journal 22: 255-265. - doi: 10.1163/2 2941932-90000283

Ramírez M, Rodríguez J, Balocchi C, Peredo M,
Elissetche JP, Mendonça R, Valenzuela S (2009). Chemical composition and wood anatomy of Eucalyptus globulus clones: variations and relationships with pulpability and handsheet properties. Journal of Wood Chemistry and Technology 29 (1): 43-58. - doi: 10.1080/027 7381080260755

Reina L, Botto E, Mantero C, Moyna P, Menéndez $P$ (2016). Production of second generation ethanol using Eucalyptus dunnii bark residues and ionic liquid pretreatment. Biomass and Bioenergy 93: 116-121. - doi: 10.1016/j.biombioe.201 6.06.023

Resquin F, Navarro-Cerrillo RM, Carrasco-Letelier L, Casnati CR (2019). Influence of contrasting stocking densities on the dynamics of aboveground biomass and wood density of Eucalyptus benthamii, Eucalyptus dunnii, and Eucalyptus grandis for bioenergy in Uruguay. Forest Ecology and Management 438: 63-74. - doi: 10.1016/j.foreco.2019.02.007

Rocha MFV, Pereira BC, Oliveira AC, Pego MFF, Veiga TRLA, Carneiro ACO (2018). Influence of plant spacing on the bark properties of Eucalyptus clone. Revista Arvore 42 (5): e420501. doi: 10.1590/1806-90882018000500001

Rocha MFV, Vital BR, Carneiro ACO, Carvalho AMML, Cardoso MT, Hein PRG (2016). Effect of plant spacing on the physical, chemical and energy properties of Eucalyptus wood and bark. Journal of Tropical Forest Science 28 (3): 243248.

Romaní A, Yánez R, García A, Cancelas A, Angel $S$, Teixeira JA, Domingues L (2018). Potential of Eucalyptus bark for biofuels production. In: Proceedings of the " $4^{\text {th }}$ Iberoamerican Congress on Biorefineries". Jaén (Spain) 24-26 Oct 2018, vol. 48, pp. 63-68. [online] URL: http://re positorium.sdum.uminho.pt/handle/1822/58329 Sarin V, Pant KK (2006). Removal of chromium from industrial waste by using Eucalyptus bark. Bioresource Technology 97 (1): 15-20. - doi: 10.1016/j.biortech.2005.02.010

Scolforo HF, Castro Neto F, Scolforo JRS, Burkhart H, McTague JP, Raimundo MR, Loos RA, Fonseca S, Sartório RC (2016). Modeling dominant height growth of Eucalyptus plantations with parameters conditioned to climatic variations. Forest Ecology and Management 380: 182-195. - doi: 10.1016/j.foreco.2016.09.001 Sette CRJ, Hansted ALS, Novaes E, Fonseca e Lima PA, Rodrigues AC, Santos DRS, Yamaji FM (2018). Energy enhancement of the Eucalyptus bark by briquette production. Industrial Crops and Products 122: 209-213. - doi: 10.1016/j.inder op.2018.05.057

Silva CL, Roldão BC, Santos LDT, Hein PRG (2018). Lenho e casca de Eucalyptus e Acacia em plantios monoespecíficos e consorciados [Wood and bark of Eucalyptus and Acacia in monospecific and consorciated plantings]. Floresta e Ambiente 25 (1): eooo81914. [in Portuguese] - doi: 10.1590/2179-8087.081914

Vázquez G, Fontenla E, Santos J, Freire MS, González-Alvarez J, Antorrena G (2008). Antioxidant activity and phenolic content of chestnut (Castanea sativa) shell and eucalyptus (Eucalyptus globulus) bark extracts. Industrial Crops and Products 28 (3): 279-285. - doi: 10.1016/j.indcrop. 2008.03.003

Weerakkody NS, Caffin N, Lambert LK, Turner 
MS, Dykes GA (2011). Synergistic antimicrobial activity of galangal (Alpinia galanga), rosemary (Rosmarinus officinalis) and lemon iron bark (Eucalyptus staigerana) extracts. Journal Science of Food and Agriculture 91: 461-468. - doi: 10.1002/jsfa.4206

Will RE, Narahari NV, Shiver BD, Teskey RO (2005). Effects of planting density on canopy dynamics and stem growth for intensively managed loblolly pine stands. Forest Ecology and
Management 205 (1-3): 29-41. - doi: 10.1016/j.for eco.2004.10.002

Zobel B, Jett JB (1995). Genetics of wood production. Springer-Verlag, Berlin, Germany, pp. 336. 